CZASOPISMO INŻYNIERII LĄDOWEJ, ŚRODOWISKA I ARCHITEKTURY JOURNAL OF CIVIL ENGINEERING, ENVIRONMENT AND ARCHITECTURE

JCEEA, t. XXXIII, z. 63 (3/16), lipiec-wrzesień 2016, s. 201-210

Jan KRUPA ${ }^{1}$

Andrzej MANTAJ ${ }^{2}$

Piotr KOSZELNIK ${ }^{3}$

\title{
GOSPODARKA ENERGETYCZNA A OCHRONA ŚRODOWISKA W OPINII RÓŻNYCH GRUP RESPONDENTÓW. Część 1
}

\begin{abstract}
Celem badań była ocena prezentowanych przez respondentów opinii w zakresie szeroko rozumianej gospodarki energetycznej, z uwzględnieniem jej oddziaływania na środowisko oraz znaczenia różnych nośników energii. Analizę oparto na 1036 kwestionariuszach ankiet, wypełnionych w okresie październik - grudzień 2015 r. W niniejszej części opracowania poddano analizie kształtowanie się ocen ankietowanych osób bez uwzględniania opisujących je charakterystyk. Stwierdzono, że w opinii respondentów poziom wiedzy społeczeństwa w zakresie ochrony środowiska, a zwłaszcza przyrody jest ciągle niski, natomiast wpływ człowieka na globalne ocieplenie - znaczny. Za najgroźniejsze gazy cieplarniane, z uwagi na skalę ich oddziaływania, uznano, w kolejności ich ważności: dwutlenek węgla, freony i halony, metan, tlenki siarki, tlenki azotu oraz parę wodną. Zastosowanie trzech najważniejszych tradycyjnych źródeł energii (węgiel kamienny, gaz i węgiel brunatny) dla kraju i województwa podkarpackiego uznano za takie samo, przy czym energetyce jądrowej dla podkarpackiej gospodarki przypisano mniejszą atrakcyjność, aniżeli dla Polski. Skłonność do zamiany pieca węglowego na bardziej ekologiczne źródło energii wyraziła prawie połowa respondentów, a tylko jedna piąta ich liczby akceptuje budowę siłowni atomowej. Przeprowadzona analiza dowodzi dużych rozbieżności między opiniami respondentów, a stanem rzeczywistym problematyki będącej przedmiotem badań. Wynika stąd potrzeba szerszego informowania społeczeństwa o stanie i kierunkach rozwoju gospodarki energetycznej w oparciu o rzetelne $\mathrm{i}$ aktualne argumenty.
\end{abstract}

Słowa kluczowe: emisja zanieczyszczeń, zanieczyszczenie klimatu, konsultacje społeczne, energetyka jądrowa

\footnotetext{
${ }^{1}$ Autor do korespondencji / corresponding author: Jan Krupa, Wyższa Szkoła Informatyki i Zarządzania w Rzeszowie, e-mail: jkrupa@wsiz.rzeszow.pl

2 Andrzej Mantaj, Wyższa Szkoła Informatyki i Zarządzania w Rzeszowie

${ }^{3}$ Piotr Koszelnik, Politechnika Rzeszowska im. I. Łukasiewicza, Wydział Budownictwa Inżynierii Środowiska i Architektury, pkoszel@prz.edu.pl
} 


\section{Wprowadzenie}

Za jedną z najważniejszych przyczyn współczesnych zmian klimatu uznaje się emisję $\mathrm{CO}_{2}$ w wyniku spalania paliw kopalnych, tj. ropy, gazu i węgla. Toksyczność atmosfery, będąca wynikiem spalania paliw ze źródeł nieodnawialnych jest obecnie przedmiotem ciągłych badań. Ze spalania tylko samego węgla w naszym kraju powstaje w ciągu roku około 4-5 milinów ton zanieczyszczeń stałych oraz duże ilości zanieczyszczeń gazowych. Szacuje się, że z powodu zanieczyszczenia powietrza umiera w Polsce około 45 tys. osób rocznie, m.in. z powodu ponadnormatywnego stężenia np. pyłu zawieszonego, który wywołuje choroby płuc i układu krążenia [5]. Europejska Agencja Ochrony Środowiska (EEA) opracowała ranking, według którego aż 6 polskich miast znajduje się w pierwszej dziesiątce tych najbardziej zanieczyszczonych w Europie. Wynika to m.in. z niskiej jakości powietrza powodowanej wysoką energochłonnością budynków.

Znaczący wpływ na jakość środowiska przyrodniczego w Polsce ma elektroenergetyka. [8]. Oddziaływanie to powodowane jest nie tylko zużywaniem energetycznych surowców kopalnych, ale także zanieczyszczaniem środowiska naturalnego gazami, pyłami i innymi odpadami procesu spalania. Konkurencja między elektrowniami wymusza ich dostosowywanie się do zaostrzonych wymagań środowiskowych i ekonomicznych oraz do zmieniającego się otoczenia. Dla jednych elektrowni stanowi to szansę, a dla innych jest to poważne zagrożenie. $\mathrm{Z}$ uwagi na członkostwo w UE, Polska została zobowiązana do wypełniania szeregu warunków związanych $\mathrm{z}$ ochroną środowiska, wcześniej nie branych pod uwagę. Ekologicznymi celami polityki energetycznej UE są, m.in.: redukcja emisji dwutlenku węgla, jako dominującego gazu cieplarnianego, oraz zmiana struktury paliw, w tym wzrost udziału energii odnawialnej w zużyciu energii.

Rozwój społeczno-gospodarczy oraz potrzeba chwili sprawiają, że istnieje konieczność zastosowania w zakresie ochrony środowiska racjonalnych rozwiązań. Wyraża je także zasada zrównoważonego rozwoju, która określona została w wielu ustawach i rozporządzeniach UE. Przedstawione w pracy wyniki badań mają na celu prezentację tej problematyki w odniesieniu do kraju, a w szczególności do województwa podkarpackiego, a jej wyrazem są opinie, wiedza i działania praktyczne badanych respondentów, świadczące o poziomie ich świadomości ekologicznej.

Celem opracowania była ocena prezentowanych przez respondentów opinii w zakresie szeroko rozumianej gospodarki energetycznej, z uwzględnieniem jej oddziaływania na środowisko oraz znaczenia różnych nośników energii. Materiał badawczy uzyskano na podstawie analizy danych z kwestionariuszy ankiet wypełnionych przez osoby zamieszkujące w zdecydowanej większości teren województwa podkarpackiego. W niniejszej części opracowania zaprezentowano zebrane opinie bez uwzględniania opisujących respondentów charakterystyk. Ocena oddziaływania tych charakterystyk, jako uwarunkowań wyrażanych poglądów, będzie przedmiotem interpretacji zawartej w drugiej części artykułu. Przedstawiona tu analiza ma więc na celu przede wszystkim uchwycenie dominujących tendencji poglądów zakresie problematyki będącej przedmiotem badania. 


\section{Materiał źródłowy i metodyka analizy wyników badań}

Podstawę przeprowadzonej analizy stanowiły wypełnione, przez 1036 osób w okresie październik - grudzień 2015 r., kwestionariusze ankiet. Wśród respondentów zdecydowanie dominowali mieszkańcy województwa podkarpackiego (995), a ponadto pochodzili oni z województw: lubelskiego (21), małopolskiego (15) oraz śląskiego (5). Nie wszystkie spośród kwestionariuszy zawierały komplety odpowiedzi, w związku z czym przy opisie poszczególnych problemów podano rzeczywistą liczbę wypowiedzi dotyczącą danego zagadnienia.

Respondenci wyrażali swoje opinie głównie poprzez wybór jednego z trzech poziomów akceptacji podanych określeń opisujących przedmiot badania, przy czym 1 oznaczało zawsze najwyższy stopień jego aprobaty. Pozostała część wypowiedzi miała charakter zero-jedynkowy i polegała na przyjęciu lub odrzuceniu danego poglądu.

Opinie badanych osób zebrano w dwuwymiarowych tablicach zawierających odsetki wypowiedzi wskazujących stopień znaczenia lub, w przypadku odpowiedzi zero-jedynkowych, fakt akceptacji podanych określeń. Tablice te stanowiły więc sposób prezentacji danych, a jednocześnie podstawę analizy wyników badań [6].

\section{Analiza wyników badań}

Przed rozpoczęciem analizy przedstawione zostały charakterystyki osób, które brały udział w ankietyzacji, a następnie ich opinie w całej badanej próbie, jednak bez uwzględniania determinant wypowiedzi. Rozkłady ocen respondentów na tle ich charakterystyk zostały omówione w drugiej części opracowania.

Charakterystyki opisujące badane osoby ze względu na ich wiek, płeć, miejsce zamieszkania, wykształcenie oraz stopień zainteresowania problematyką w zakresie ochrony środowiska podano w tabeli 1 .

Tabela 1. Charakterystyka respondentów

Table 1. The characteristics of the respondent

\begin{tabular}{|c|c|c|c|c|c|c|c|c|c|c|}
\hline \multirow{2}{*}{$\begin{array}{c}\text { Wyszczegól- } \\
\text { nienie }\end{array}$} & \multicolumn{9}{|c|}{ Wiek (lata) } & \multicolumn{2}{|c|}{ Pleć } & \multicolumn{2}{|c|}{ Zamieszkanie } & \multicolumn{2}{|c|}{ Wykształcenie } & \multicolumn{2}{|c|}{$\begin{array}{c}\text { Zaintereso- } \\
\text { wanie ochro- } \\
\text { ną środow. }\end{array}$} \\
\cline { 2 - 11 } & $\mathbf{5 2 5}$ & $\mathbf{7 2 5}$ & $\mathbf{K}$ & $\mathbf{M}$ & Wieśn & Miasto & $\begin{array}{c}\text { Zaw./ } \\
\text { Śr. }\end{array}$ & $\begin{array}{c}\text { Wyż- } \\
\text { sze }\end{array}$ & Mała & Duża \\
\hline $\begin{array}{c}\text { Liczba } \\
\text { respondentów }\end{array}$ & 416 & 620 & 617 & 419 & 570 & 466 & 648 & 388 & 838 & 198 \\
\hline $\begin{array}{c}\text { Odsetek } \\
\text { respondentów } \\
{[\%]}\end{array}$ & 40,2 & 59,8 & 59,6 & 40,4 & 55,0 & 45,0 & 62,5 & 37,5 & 80,9 & 19,1 \\
\hline
\end{tabular}

Źródło: opracowanie własne 
Około $60 \%$ liczby respondentów stanowiły osoby w wieku powyżej 25 lat oraz kobiety, osoby z wykształceniem średnim lub zawodowym - 62,5\% i 55\% mieszkańcy wsi. Duże zainteresowanie ochroną środowiska wykazało $19,1 \%$ ankietowanych. Oznacza to podobny rozkład liczby osób z uwagi na wiek, płeć i wykształcenie oraz zbliżony do poprzednich - ze względu na miejsce zamieszkania.

$\mathrm{Z}$ uwagi na to, że energetyka w kontekście ochrony środowiska kojarzona jest najczęściej z jej wpływem na emisję gazów i związanym z nią globalnym ociepleniem, w tabeli 2 przedstawiono opinie dotyczące tego zjawiska, a także wyrażoną przez ankietowanych ocenę poziomu wiedzy społeczeństwa dotyczącą zagadnień ochrony środowiska.

Tabela 2. Poziom wiedzy społeczeństwa dotyczącej ochrony środowiska i wpływu człowieka na globalne ocieplenie wg odsetek 1036 wypowiedzi [\%]

Table 2. The level of public awareness concerning the protection of the environment and the human impact on global warming. The percentage of 1036 expressions [\%]

\begin{tabular}{|c|c|c|c|}
\hline Wyszczególnienie & \multicolumn{3}{|c|}{ Skala zjawiska } \\
\cline { 2 - 4 } & $\mathbf{1}$ & $\mathbf{2}$ & $\mathbf{3}$ \\
\hline Wiedza społeczeństwa dotycząca ochrony środowiska & 11,1 & 34,0 & 54,9 \\
\hline Wpływ człowieka na globalne ocieplenie & 57,4 & 27,4 & 15,2 \\
\hline
\end{tabular}

Źródło: opracowanie własne

Łatwo można zauważyć, że poziom tej wiedzy w społeczeństwie, wg opinii respondentów, jest niewielki, ponieważ najwyższy jej stopień przypisany został tylko ok. $11 \%$ obywateli, a ponad ich połowa została uznana za posiadającą tylko słabą znajomość tej problematyki. Z kolei ponad 57\% osób uznało wpływ człowieka na globalne ocieplenie za bardzo istotny.

Wpływ gazów emitowanych z różnych źródeł na stan środowiska uzależniony jest zarówno od ich ilości, jak i rodzaju. W tabeli 3 podano częstości opinii dotyczących udziału i szkodliwości gazów cieplarnianych z uwagi na powszech-

Tabela 3. Szkodliwość gazów cieplarnianych ze względu na skalę ich oddziaływania na zdrowie człowieka wg odsetek 1036 wypowiedzi [\%]

Table 3. The harmfulness of greenhouse gases due to the scale of their impact on human health. The percentage of 1036 expressions [\%]

\begin{tabular}{|c|c|c|}
\hline \multirow{2}{*}{ Rodzaj gazu } & \multicolumn{2}{|c|}{ Wskazania } \\
\cline { 2 - 3 } & Liczba & Odsetek \\
\hline Dwutlenek wegla & 315 & 30,4 \\
\hline Freony i halony & 226 & 21,8 \\
\hline Metan & 203 & 19,6 \\
\hline Tlenki siarki & 172 & 16,6 \\
\hline Tlenki azotu & 80 & 7,7 \\
\hline Para wodna & 40 & 3,9 \\
\hline
\end{tabular}

Źródło: opracowanie własne 
ność i niebezpieczeństwo ich oddziaływania na zdrowie człowieka. Około 30\% osób wskazało w tym względzie na dwutlenek węgla, a na następne, co do udziału i szkodliwości - tlenki azotu, już tylko niespełna 8\% ankietowanych. Świadczy to o stosunkowo dobrej znajomości tego problemu, bowiem udział $\mathrm{CO}_{2} \mathrm{w}$ strukturze wszystkich gazów cieplarnianych określany jest na poziomie ok. 50\%, natomiast udział związków azotu stanowi ok. 18\% [2]. Z kolei udział $\mathrm{CO}_{2}$, według jego bezpośredniego wpływu na efekt cieplarniany, określany jest na poziomie od 9-26\%, metanu 4-9\%, natomiast największy udział przypisywany jest parze wodnej 36-72\%, która należy do najpowszechniejszych gazów cieplarnianych w atmosferze [3].

Należy tu jednak zaznaczyć, że antropogeniczna emisja dwutlenku węgla jest pięciokrotnie mniejsza od naturalnej, przy zdefiniowaniu jej jako działalności wulkanicznej i procesów zachodzących w glebie [4]. Całkowita emisja gazów cieplarnianych spadła o blisko $30 \%$ od początku transformacji polskiej gospodarki, natomiast emisje pochodzące $\mathrm{z}$ transportu wzrosły o niemal $75 \%$, co jest wywołane intensywnym rozwojem motoryzacji, przy spadku udziału transportu kolejowego w przemieszczaniu towarów.

Problem globalnego ocieplenia budzi wiele kontrowersji. Pytania o skutki globalnego wzrostu temperatury, wpływu poszczególnych gazów oraz działalności człowieka na zmianę klimatu, pomimo różnych opinii, mają istotne znaczenie i zasługują na szczegółowe badania wyjaśniające i krytyczną analizę, bowiem przecenianie wagi efektu cieplarnianego przy zbyt wielkich restrykcjach w zużyciu paliw może doprowadzić do zahamowania rozwoju cywilizacyjnego, a niedocenianie - katastrofę środowiska naturalnego [7]. Ważna więc wydaje się w dalszym ciągu ocena tego zagrożenia, stały monitoring zanieczyszczeń atmosfery i próby ograniczania emisji szkodliwych gazów podejmowane przez poszczególne państwa. Działania te powinny mieć charakter globalny, przy czym powszechnie niedoceniany bezpośredni wpływ każdego mieszkańca naszej planety w powyższym zakresie może jednak negatywnie wpływać na indywidualne działania mające na celu ograniczanie emisji rodzajów gazów.

Częstym przedmiotem dyskusji w środkach masowego przekazu jest wybór odpowiednich źródeł energii wykorzystywanych w gospodarce, a w tabeli 4 przedstawiono dotyczącą tego zagadnienia strukturę częstości opinii badanych osób.

Tabela 4. Tradycyjne źródła energii i ich znaczenie dla gospodarki Polski wg odsetek 991 wypowiedzi [\%]

Table 4. Traditional energy sources and their significance in Polish economy. The percentage of 991 expressions [\%]

\begin{tabular}{|c|c|c|c|}
\hline \multirow{2}{*}{ Źródła energii } & \multicolumn{3}{|c|}{ Znaczenie źródeł energii } \\
\cline { 2 - 4 } & $\mathbf{1}$ & $\mathbf{2}$ & $\mathbf{3}$ \\
\hline Węgiel kamienny & 48,3 & 26,1 & 25,6 \\
\hline Gaz & 44,5 & 44,2 & 13,3 \\
\hline Węgiel brunatny & 38,0 & 35,1 & 26,9 \\
\hline Lupki bitumiczne & 25,1 & 25,4 & 49,4 \\
\hline Ropa & 22,7 & 48,1 & 29,2 \\
\hline Energia jądrowa & 21,3 & 23,0 & 55,7 \\
\hline
\end{tabular}

Źródło: opracowanie własne 
Najwięcej (ok. 48\%) z nich za najważniejsze w tym względzie źródło energii podało węgiel kamienny $\mathrm{i}$ jest to zgodne z aktualną polityką rządu. Następną pozycję wśród źródeł energii stanowił gaz. Co prawda korzystanie z niego uwarunkowane jest importem tego surowca, to jednak produkty jego spalania są zdecydowanie mniej uciążliwe dla środowiska i zdrowia człowieka, aniżeli emisje będące wynikiem spalania węgla. Pozostałym nośnikom energii nadano mniejsze znaczenie, co wiąże się także z ich ograniczoną dostępnością. Zwraca jednak uwagę fakt, że jedna piąta respondentów do najważniejszych źródeł energii była skłonna zaakceptować elektrownie atomowe.

W innych badaniach, przeprowadzonych w 2009 r., wykazano dużą akceptację dla energetyki jądrowej (23,7\%), jako przyszłego źródło pozyskiwania energii [1]. Wyniki tych badań odniesione do uzyskanych w 2008 r. wskazały, że akceptacja energetyki jądrowej wzrosła prawie o 70\%, zajmując drugie, po surowcach i źródłach odnawialnych, miejsce wśród zaproponowanych nośników energii. Awans energetyki jądrowej wystąpił tu kosztem wszystkich pozostałych rozwiązań, przy czym na uwagę zasługuje także fakt, że największy spadek wskazań w tych badaniach dotyczył zjawiska zmniejszenia się skłonności do oszczędzania energii.

Należy jeszcze zaznaczyć, że wytwarzanie $\mathrm{CO}_{2} \mathrm{w}$ procesie spalania węgla jest tylko jednym $\mathrm{z}$ wielu czynników wpływających na zmianę klimatu na Ziemi, a gaz ten jest naturalnym składnikiem atmosfery, podobnie jak woda, metan i związki azotu, tworzące wokół Ziemi otulinę gazów cieplarnianych, niezbędnych dla istnienia życia. Działania informacyjne o dużym wpływie $\mathrm{CO}_{2}$ na globalne ocieplenie i jego szkodliwości skierowane są głównie przeciwko wykorzystywaniu energii konwencjonalnej pochodzącej ze spalania węgla kopalnego, którego zamiennika upatruje się w energii jądrowej.

Alternatywą dla nieodnawialnych źródeł energii jest energia odnawialna. Odsetki opinii respondentów dotyczących znaczenia poszczególnych jej źródeł, z jakich powinna korzystać polska gospodarka, przedstawiono w tabeli 5. Wyniki ba-

Tabela 5. Alternatywne źródła energii i ich znaczenie dla gospodarki Polski wg odsetek 968 wypowiedzi [\%]

Table 5. Alternative energy sources and their importance to the Polish economy The percentage of 991 expressions [\%]

\begin{tabular}{|c|c|c|c|}
\hline \multirow{2}{*}{ Źródła energii } & \multicolumn{3}{|c|}{ Znaczenie źródeł energii } \\
\cline { 2 - 4 } & $\mathbf{1}$ & $\mathbf{2}$ & $\mathbf{3}$ \\
\hline Kolektory słoneczne & 58,1 & 34,3 & 7,6 \\
\hline Ogniwa fotowoltaiczne & 45,9 & 44,4 & 9,7 \\
\hline Energia wiatru & 31,8 & 56,2 & 12,0 \\
\hline Energia wodna & 19,8 & 67,1 & 13,0 \\
\hline Biomasa & 12,2 & 54,4 & 33,4 \\
\hline Geotermia & 11,8 & 56,9 & 31,3 \\
\hline Drewno & 10,9 & 33,3 & 55,8 \\
\hline Biogaz & 9,5 & 53,3 & 37,2 \\
\hline
\end{tabular}

Źródło: opracowanie własne 
dań wskazują, że najczęściej w tym zakresie spośród urządzeń umożliwiających pozyskiwanie energii odnawialnej wymieniano kolektory słoneczne oraz ogniwa fotowoltaiczne, a następnie elektrownie wiatrowe. Zapewne są to najbardziej czyste odnawialne źródła energii, aczkolwiek mocno uzależnione od warunków pogodowych i ze względów technicznych, ciągle o stosunkowo niskim potencjale.

Ponadto wskazano, aczkolwiek w dużo mniejszym stopniu, na znaczenie energii wodnej oraz geotermii, a dopiero potem na produkcję biomasy. Przedstawione opinie, dotyczące najważniejszych sposobów pozyskiwania energii, mogą odbiegać od powszechnie panujących w tej dziedzinie poglądów, zwłaszcza wśród profesjonalistów.

W badaniach przeprowadzonych w 2009 r. stwierdzono, że większą wagę w zakresie ochrony zasobów naturalnych, przykłada się do zmian technologicznych niż do zmiany nawyków konsumpcyjnych czy edukacji, np. poprzez popularyzację oszczędzania energii i surowców do jej produkcji, co nie napawa optymizmem [1]. Należy jednak podkreślić, że w Polsce ok. 85\% emisji gazów cieplarnianych jest związanych z sektorem energii - głównie elektrowni węglowych [4].

Spośród źródeł energii, które powinna wykorzystywać gospodarka podkarpacka, za najważniejsze uznano węgiel i gaz ziemny, a następnie węgiel brunatny oraz ropę naftową, na co wskazują zebrane dane w tabeli 6 .

Tabela 6. Alternatywne źródła energii, z jakich powinna korzystać gospodarka podkarpacka i ich ranga wg odsetek 987 wypowiedzi [\%]

Table 6. Alternative energy sources and their importance to the Podkarpackie Voivodeship economy. The percentage of 987 expressions [\%]

\begin{tabular}{|c|c|c|c|}
\hline \multirow{2}{*}{ Źródła energii } & \multicolumn{3}{|c|}{ Znaczenie źródeł energii } \\
\cline { 2 - 4 } & $\mathbf{1}$ & $\mathbf{2}$ & $\mathbf{3}$ \\
\hline Węgiel kamienny & 45,6 & 27,6 & 26,8 \\
\hline Gaz & 45,5 & 39,6 & 14,9 \\
\hline Węgiel brunatny & 32,9 & 37,6 & 29,5 \\
\hline Ropa & 28,7 & 44,8 & 26,5 \\
\hline Lupki bitumiczne & 27,2 & 27,0 & 45,8 \\
\hline Energia jądrowa & 20,2 & 23,4 & 56,4 \\
\hline
\end{tabular}

Źródło: opracowanie własne

Ranga pierwszych trzech rodzajów źródeł jest analogiczna, jak w przypadku ich znaczenia dla całego kraju, natomiast różnice zauważyć można na dalszych pozycjach tego uszeregowania. Energetyka jądrowa znalazła się na ostatnim miejscu w obu rozważanych przypadkach, ale nieco mniejszy odsetek respondentów wskazał ją jako ważną dla województwa podkarpackiego, co może być zrozumiałe z uwagi na przypisywane jej zagrożenia dla jakości środowiska oraz zdrowia i życia człowieka.

Opinie respondentów dotyczące możliwości wykorzystania energii odnawialnej w mieszkalnictwie przedstawiono w tabeli 7. Z uwagi na duży odsetek osób w Polsce zamieszkujących we własnych budynkach jedno- lub wielorodzinnych 
Tabela 7. Alternatywne źródła energii, z jakich powinno korzystać mieszkalnictwo i ich ranga wg odsetek 982 wypowiedzi [\%]

Table 7. Alternative energy sources, which should benefit from housing. Opinion of 982 respondents [\%]

\begin{tabular}{|c|c|c|c|}
\hline \multirow{2}{*}{ Źródła energii } & \multicolumn{3}{|c|}{ Znaczenie źródeł energii } \\
\cline { 2 - 4 } & $\mathbf{1}$ & $\mathbf{2}$ & $\mathbf{3}$ \\
\hline Kolektory słoneczne & 66,3 & 27,5 & 6,2 \\
\hline Ogniwa fotowoltaiczne & 51,5 & 38,2 & 10,3 \\
\hline Energia wiatru & 25,7 & 61,1 & 13,2 \\
\hline Drewno & 14,9 & 41,1 & 44,0 \\
\hline Biomasa & 11,5 & 55,3 & 33,2 \\
\hline Energia wodna & 11,1 & 69,3 & 19,6 \\
\hline Biogaz & 10,4 & 53,0 & 36,6 \\
\hline Geotermia & 8,6 & 54,4 & 37,0 \\
\hline
\end{tabular}

Źródło: opracowanie własne

oraz w starym budownictwie, wskazane poprzednio uszeregowanie ze względu na znaczenie źródeł energii dla gospodarki znajduje tu analogiczny, a jednocześnie jeszcze bardziej jednoznaczny wyraz. Najczęściej więc, jako najbardziej znaczące źródła potencjału energetycznego dla mieszkalnictwa, wybierano kolektory słoneczne, a następnie ogniwa fotowoltaiczne i farmy wiatrowe.

Ostatnim celem badań na całej próbie, bez uwzględniania uwarunkowań opinii, były oceny respondentów dotyczące ewentualnej zamiany pieca węglowego na inne źródło ogrzewania oraz stopień akceptacji budowy elektrowni atomowej, których strukturę liczebności zaprezentowano w tabeli 8.

Tabela 8. Stopień skłonności do zmiany pieca węglowego na inne źródło ogrzewania oraz akceptacji budowy elektrowni atomowej w Polsce wg odsetek 1036 wypowiedzi [\%]

Table 8 . The degree of willingness to change coal furnace for other heating source and acceptance of the nuclear power plant energy in Poland. Opinion of 1,036 respondents [\%]

\begin{tabular}{|c|c|c|c|}
\hline \multirow{2}{*}{ Rodzaje działań } & \multicolumn{3}{|c|}{ Stopień akceptacji działań } \\
\cline { 2 - 4 } & $\mathbf{1}$ & $\mathbf{2}$ & $\mathbf{3}$ \\
\hline Zamiana pieca węglowego na inne źródło ogrzewania & 47,5 & 31,9 & 20,6 \\
\hline Akceptacja budowy elektrowni atomowej & 22,4 & 30,6 & 47,0 \\
\hline
\end{tabular}

Źródło: opracowanie własne

Najwyższy odsetek (47,5\%) badanych osób, w stopniu najwyższym opowiedział się za wymianą pieca, a pozostałe osoby czyniły to w sposób tylko umiarkowany lub słaby. $Z$ kolei poziom akceptacji budowy elektrowni atomowej był zbliżony do odsetek opinii wyrażonych przy określaniu znaczenia energii otrzymywanej z rozszczepiania atomów dla gospodarki kraju i województwa podkarpackiego. Ponad $22 \%$ respondentów w stopniu najwyższym aprobowało to działanie, natomiast $47 \%$ ich liczby uznało taką budowę za mało konieczną lub zupełnie zbędną.

Przedstawiona powyżej ocena uzyskanych, w oparciu o przeprowadzone obserwacje poglądów respondentów, nie uwzględniała opisujące ich charakterystyki. 


\section{Podsumowanie}

Celem opracowania była analiza ocen respondentów w zakresie gospodarki energetycznej z uwzględnieniem jej oddziaływania na środowisko. Materiał badawczy uzyskano na podstawie 1036 ankiet wypełnionych przez osoby zamieszkujące w zdecydowanej większości teren województwa podkarpackiego. Niniejszą część opracowania poświęcono ocenie zaprezentowanych opinii bez uwzględniania charakterystyk prezentujących je osób. Respondenci uznali, że poziom wiedzy społeczeństwa $\mathrm{w}$ zakresie ochrony przyrody jest ciągle niski, natomiast wpływ człowieka na globalne ocieplenie - znaczny. Za najgroźniejsze gazy cieplarniane, z uwagi na skalę ich oddziaływania, uznano, w kolejności ich ważności: dwutlenek węgla, freony i halony, metan, tlenki siarki, tlenki azotu oraz parę wodną. Uszeregowanie trzech najważniejszych tradycyjnych źródeł energii dla kraju i województwa podkarpackiego było podobne, przy czym energetyce jądrowej dla podkarpackiej gospodarki przypisano mniejsze znaczenie, aniżeli dla Polski. Także jednakowe uporządkowanie $\mathrm{z}$ uwagi na znaczenie podano dla alternatywnych źródeł energii dla kraju oraz mieszkalnictwa. Odbiega ono jednak bardzo mocno od ich uszeregowania $\mathrm{z}$ uwagi na aktualne i planowane korzystanie $\mathrm{z}$ ich potencjału energetycznego. Ponadto skłonność do zamiany pieca węglowego na bardziej ekologiczne źródło energii wyraziła prawie połowa respondentów, a ok. 22\% ich liczby akceptuje budowę siłowni atomowej.

Przedstawiona analiza dowodzi dużych rozbieżności między opiniami respondentów, a stanem rzeczywistym problematyki będącej przedmiotem badań. Wynika stąd potrzeba szerszego informowania społeczeństwa o stanie i kierunkach rozwoju gospodarki energetycznej w oparciu o rzetelne i aktualne argumenty.

Należy podkreślić, że rozważania o degradacji środowiska oraz zmianach klimatycznych i konsekwencjach globalnego ocieplenia grożącym żywym organizmom na Ziemi, są często źródłem kontrowersji i nie do końca potwierdzonych stwierdzeń. Niepewność ocen i duży margines ciągle niewyjaśnionych procesów fizycznych nie zwalnia ludzkości od odpowiedzialności za stan środowiska. Postawa proekologiczna i systematyczna dbałość o środowisko będzie wymuszać uwzględniający te wymogi rozwój nowych technologii i z pewnością wpłynie korzystnie na jakość naszego życia i zdrowia.

\section{Literatura}

[1] Bołtromiuk A., Świadomość ekologiczna Polaków - zrównoważony rozwój - raport z ba-dań 2009, INSTYTUT NA RZECZ EKOROZWOJU, na podstawie: http://www.ine-isd.org.pl/ 2009.pdf (dostęp:16-06-2016).

[2] Główny Inspektorat Środowiska, Stan środowiska w Polsce, Raport 2014, Biblioteka Monitoringu Środowiska, Warszawa 2014, s. 162-170, na podstawie: http://www.gios.gov.pl/pl/stan-srodowiska/raporty-o-stanie-srodowiska (dostęp: 16-06-2016). 
[3] Kiehl J.T., Kevin E. Trenberth, Earths annual global mean Energy budget, „Bulletin of the American Meteorological Society", 78, 2006, s. 197-208.

[4] Kucowski J., Laudyn D., Przekwas M., Energetyka a ochrona środowiska, Wyd. Nauko-Techniczne, Warszawa 1997, s. 21-39.

[5] Sawczuk P., Dom, który oszczędza, „Human”, Nr 2(3), 2016, s. 50-53.

[6] Steczkowski J. Opis statystyczny, Pozyskiwanie i analizowanie informacji, Wyższa Szkoła Informatyki i Zarządzania, Rzeszów 2005, s. 61-75.

[7] Van Loon G.W., Duffy S.J., Chemia środowiska, Wydawnictwo Naukowe PWN, Warszawa 2008, s. 201-219.

[8] Żaba-Nieroda R., Rozwój energetyki w Polsce w świetle regulacji ekologicznych, „Nauka i Gospodarka", nr 3(6), 2010, s. 63-73.Czarnecki L., Broniewski T., Henning O.: Chemia w budownictwie, Wydawnictwo Arkady, Warszawa 1994.

\section{ENERGY MANAGEMENT AND ENVIRONMENTAL PROTECTION IN THE OPINION OF THE VARIOUS CATEGORIES OF RESPONDENTS. Part 1}

\section{S u m m a r y}

The aim of the study was to evaluate the presented respondents' opinion on the broader economy, energy, taking into account its impact on the environment and the importance of various energy carriers. The analysis was based on 1,036 survey questionnaires, filled in the October - December 2015 period. This part of the study analyzed the formation of the ratings of respondents without taking into account the characteristics that describe them. It was found that the respondents level of public awareness of environmental protection, especially of nature is still low, and the human impact on global warming - significant. For the most dangerous greenhouse gases, given the scale of their impact, it was, in order of importance: carbon dioxide, chlorofluorocarbons and halons, methane, sulfur oxides, nitrogen oxides and water vapor. The use of the three most important traditional energy sources (coal, natural gas and lignite) for the country and the Podkarpackie Voivodeship considered the same, the nuclear power industry for voivodeship economy is less attractive than for the Poland as a whole. The tendency to convert the furnace coal to cleaner energy sources expressed almost half of the respondents, and only one-fifth of their number allowed to build nuclear plant. The analysis shows a wide disparity between the opinions of the respondents, and the state of the real issues of interest. Hence the need to inform the wider public about the status and development of the energy economy based on reliable and valid arguments.

Keywords: emissions of pollutants, climate pollutants, public consultation, nuclear power energy

DOI:10.7862/rb.2016.202

Przestano do redakcji: $25.08 .2016 r$.

Przyjęto do druku: 30.11.2016 r. 